\title{
QUELQUES RÉFLEXIONS SUR LE COMPORTEMENT ALIMENTAIRE OU PORC CHARCUTIER ET DE LA TRUIE REPHODUCTRICE CONSÉQUences PRATIQUES
}

\author{
L. FALIU et D. GRIESS \\ École nationale vétérinaire, Chemin des Capelles, 31 - Toulouse
}

RÉSUMÉ,

Des porcs charcutiers disposant séparément et à volonté d'orge broyée et d'un aliment de complément riche en protéines ( $29 \mathrm{p}$. Ioo) n'ont pas été capables d'équilibrer leur ration. Si la consommation d'énergie correspond aux normes admises, l'ingestion de protéines a été insuffisante et la croissance ralentie jusqu'au poids de $50 \mathrm{~kg}$. A l'abattage, les carcasses ont été très hétérogènes. Sur deux lots de porcs charcutiers alimentés une fois par jour et six jours par semaine avec un aliment granulé, la vitesse d'ingestion a peu varié passant de $27 \mathrm{~g}$ par minute et par porc entre 30 et $40 \mathrm{~kg}$ à 46 pour des porcs de $85 \mathrm{~kg}$. Cette technique déjà expérimentée en Ig68, réduisant considérablement la main-d'œuvre donne de bons résultats, indice de consommation satisfaisant et carcasses d'excellente qualité. Alimentées ad libitum avec des aliments en farine à 9 p. Ioo environ de cellulose, deux truies reproductrices ont consommé pendant presque toute la durée de la gestation la quantité d'aliment correspondant à leurs besoins. Par contre, pendant la semaine précédant la mise bas et durant toute la durée de l'allaitement la consommation spontanée a été insuffisante pour couvrir les besoins élevés des animaux. Des expériences de digestibilité réalisées sur des truies gestantes et allaitantes ont montré que si les protéines et l’E. N. A. de la ration sont bien utilisées, le $\mathrm{Ca}$ et le $\mathrm{P}$ ne sont retenus qu'en faible proportion.

\section{SUMMARY}

\section{SOME OBSERVATIONS ON FEEDING BEHAVIOUR OF GROWING-FINISHING PIGS AND OF FEMAIE BREEDING PIGS : PRACTICAL CONSEQUENCES}

Individually fed growing-finishing pigs receiving ground barley and a feed supplement rich in protein (29 p. roo) were not able to balance their ration. If the energy intake corresponds to the admitted standards, the protein intake was unsufficient and the growth slowed down until a live weight of $50 \mathrm{~kg}$. The carcasses were very heterogenous at slaughtering. Two groups of pigs fed pelleted feed once a day and 6 days per week did not show important variations as far the consumption rate $27 \mathrm{~g}$ per minute and per pig between 30 and $40 \mathrm{~kg}$ and $46 /$ minute for the pigs 
at $85 \mathrm{~kg}$ live weight. This method, already experimented in r968 and by means of which the labour is considerably saved, gives good results, satisfying food conversion and carcasses of excellent quality. Two female breeding pigs fed ad libitum a meal containing 9 p roo of cellulose, consumed an amount of food corresponding to their requirements during nearly the whole period of pregnancy. On the contrary, during the week preceding farrowing and during lactation, the spontaneous food intake was not sufficient enough according to the high requirements of the animals. Digestibility trials performed on pregnant and suckling sows showed that the utilization rate of the protein and the carbohydrates of the ration was good, but that the retention of $\mathrm{Ca}$ adn $P$ was low.

\title{
MODE DE DISTHIBUTION DE LALIMENT ET COMPORTEMENT LORS DU REPAS CHEZ LE PORC EN CROISSANGE-FINITION
}

\author{
C. FÉVRIER \\ Station de Recherches sur l'Élevage des Porcs, \\ Centre national de Recherches zootechniques, 78 -Jouy-en-Josas \\ Institut national de la Recherche agronomique
}

\section{RÉSUMÉ}

La distribution biquotidienne et rationnée d'un aliment à base de céréales sous forme de granulé, de farine mouillée lors de la distribution, ou trempée, soit à froid, soit à $40^{\circ} \mathrm{C}$ pendant 4 heures a été réalisée au cours de deux répétitions portant chacune sur $4^{8}$ porcs en croissancefinition. Le taux de dilution était de 2,25 litres d'eau par kilogramme d'aliment. Il a été observé que le granulé et la farine mouillée permettaient les mêmes performances alors que la farine trempée donnait des résultats légèrement inférieurs quelle que soit la température. A l'abattage les femelles étaient plus maigres que les mâles castrés mais il n'a pas été observé de différences suivant les traitements. Au cours de la période de finition le comportement des porcs lors du repas a été observé. Ceci a été réalisé à distance grâce à un circuit de télévision et à un magnétoscope qui a permis de déterminer les temps de consommation avec précision. Les porcs recevant l'aliment granulé ont été plus lents à le consommer que ceux qui le recevaicnt sous les trois autres formes pour lesquelles les temps n'étaient pas significativement différents. D'une manière générale la vitesse d'ingestion augmente avec l'âge. Ainsi à $53 \mathrm{~kg}$ de poids vif un $\mathrm{kg}$ d'aliment granulé est consommé en $2 \mathrm{I} \mathrm{mn}$ contre $\mathrm{I}_{4} \mathrm{mn}$ pour la pâtée. A $75 \mathrm{~kg}$ les temps sont réduits à $\mathrm{I}_{5} \mathrm{mn}$ et $8 \mathrm{mn}$. Pour l'aliment granulé il n'a pas été observé de corrélation entre la vitesse d'ingestion et la vitesse de croissance alors que pour la pâtée le coefficient de corrélation est de - 0,502 , hautement significatif. On peut donc supposer qu'en alimentation rationnée sous forme humide, les animaux à vitesse d'ingestion rapide consomment une partie de la ration de leurs congénères et ont ainsi une croissance plus rapide. 